\title{
Media Pembelajaran Video Produk Kreatif dalam Pembuatan Softcase Laptop Produk Kreatif di Era Pandemi Covid-19
}

\author{
Yayuk Dwi Astuti \\ e-mail: kinasihku.5@gmail.com \\ SMA Negeri 1 Bungkal Ponorogo \\ Nik Haryanti \\ e-mail: nikharyanti1983@gmail.com \\ IAI Pangeran Diponegoro Nganjuk
}

\begin{abstract}
ABSTRAK: Penggunaan media dalam proses pembelajaran dapat membangkitkan keinginan-keinginan dan minat yang baru, membangkitkan motivasi, dan rangsangan kegiatan belajar, bahkan membawa pengaruhpengaruh psikologis terhadap siswa. Tampaknya pelajaran kewirausahaan siswa sebagian belum ada keinginan untuk berwirausaha. Pembuatan media video tutorial ini diharapkan dapat tumbuh imajinasi kreatifitas dari setiap siswa terkait wirausaha produk kreatif wadah laptop. Penelitian ini termasuk dalam jenis penelitian teoritis yaitu studi kepustakaan (Library Research). Hal ini dimaksudkan untuk menghimpun data dan informasi lain yang mempunyai kaitan dengan topik penelitian ini yang berasal dari karya ilmiah, atau karya tulis yang sudah ada sebelumnya. Teknik analisis data yang digunakan yaitu content analysis adalah metodologi penelitian dari sebuah dokumen. Hasil penelitiannya yaitu: Produk kreatif menekankan hasil dari proses kreativitas yang orisinil. Produk kreatif dan kewirausahaan sebagai upaya penciptaan produk baru yang dihasilkan dari proses kreatif serta memperhatikan nilai-nilai kewirausahaan yang memiliki nilai jual. Pembelajaran produk kreatif dan kewirausahaan siswa diharapkan dapat memahami sikap dan perilaku wirausahawan, menganalisis konsep desain produk barang dan jasa, menerapkan strategi teknik pemasaran serta membuat perencanaan bisnis. Media audio visual sebagai media pengajaran dan media pendidikan yang mengaktifkan mata dan telinga peserta didik dalam waktu proses belajar mengajar berlangsung, sehingga kegiatan pembelajaran dapat berjalan sesuai dengan tujuan pendidikan.
\end{abstract}

\section{Kata kunci: Media pembelajaran video, Produk kreatif, Softcase laptop}

\begin{abstract}
The use of media in the learning process can generate new desires and interests, generate motivation, and stimulate learning activities, and even bring psychological effects on students. It seems that in student entrepreneurship lessons, there is no desire for entrepreneurship. The making of video tutorial media is expected to grow the creative imagination of every student related to entrepreneurial creative products for laptop containers. This research is included in the type of theoretical research, namely library research. This is intended to collect data and other information related to the topic of this research which comes from scientific works or pre-existing papers. The data analysis technique used is content analysis, which is a research methodology from a document. The results of his research are: Creative products emphasize the results of the original creativity process. Creative and entrepreneurial products as an effort to create new products resulting from the creative process as well as paying attention to entrepreneurial values that have selling value. Learning creative products and entrepreneurship students are expected to be able to understand the attitudes and behavior of entrepreneurs, analyze the concept of product and service product design, apply marketing technique strategies and make business plans. Audio visual media as teaching media and educational media that activate the eyes and ears of students during the teaching and learning process, so that learning activities can run according to educational goals.
\end{abstract}

Keywords: Video learning media, Creative products, Laptop softcases 


\section{PENDAHULUAN}

Proses pendidikan di Indonesia senantiasa mengalami perbaikan ataupun penyempurnaan yang dapat menghasilkan pendidikan yang bermutu. Pendidikan yang berkualitas diperoleh dari pengelolaan pendidikan yang baik untuk meningkatkan kemandirian belajar pada peserta didik. Hal ni menjadi langkah awal agar dapat memperoleh kualitas sumber daya manusia. Rendahnya mutu pendidikan dapat dilihat dari berbagai siswa yang mendapatkan nilai tinggi tetapi masih kurang mampu menerapkan perolehannya baik berupa pengetahuan, ketrampilan dan skap (Ekawati, Wahyuningsih, \& Fisika, 2012).

Salah satu cara untuk meningkatkan pendidian berkualitas diantaranya adalah meningkatan kemandirian siswa untuk belajar. Kemandirian dapat dilihat dari kemantapan untuk mencapi tujuan. Kemandirian sebagai kebebasan untuk menentukan masa depannya sendiri, dengan demikian menunjukkan bahwa seseorang dalam perencanaan kehidupannya ditentukan oleh diri sendiri. Seseorang dikatakan mandiri akan berusaha untuk mengejar prestasi, rajin belajar, merencanakan serta mewujudkan harapannya (Sa'diyah, 2017).

Belajar mandiri dilakukan dengan peserta didik tidak menggantungkan sepenuhnya kepada guru. Peserta didik cenderung mencari sendiri informasi atau pengetahuan yang belum diketahui terkait materi pelajaran yang belum diketahuinya. Mengingat adanya wabah covid-19 yang sekarang menjadi pandemi global, sehingga kegiatan pembelajaran dilaukan secara online. Hal ini menjadi kesempatan pada peserta didik untuk belajar mandiri di rumah dengan membuat video produk kreatif yaitu wadah laptop. Akan tetapi banyak peserta didik yang mengalami kesulitan dikarenakan signal kurang bagus, sehingga diperlukan bahan ajar yang dapat digunakan peserta didik untuk belajar mandiri di era pandemi global (Rintan Saragih, 2017).

Berkenaan dengan penyebaran Coronavirus Disease (covid 19) yang semakin meningkat maka kesehatan seluruh warga sekolah menjadi pertimbangan utama dalam pelaksanaan kebijakan pendidikan. Edaran Menteri Pendidikan dan Kebudayaan Republik Indonesia Nomor 4 tahun 2020 tentang Pelaksanaan Kebijakan Pendidikan Dalam Masa Darurat Penyebaran Corona Virus Disease (COVID-19). Dengan ini dalam poin 2.a menyatakan kegiatan pembelajaran dilakukan melalui sistem belajar dari rumah yang mana memanfaatkan pembeljaran daring/ jarak jauh dilaksanakan untuk memberikan pengalaman belajar yang bermakna bagi siswa tanpa terbebani tuntutan menuntaskan seluruh capaian kurikulum untuk kenaikan kelas ataupun kelulusan(Argaheni, 2020). Selain itu, siswa harus punya pendamping belajar, hal ini terjadi karena nilai KKM siswa di sekolah minim. Terutama masalah pelajaran PKK (Produk Kreatif dan Kewirausahaan) siswa sebagian belum ada keinginan untuk berwirausaha. Dengan wujud media video tutorial ini dapat tumbuh imajinasi kreatifitas dari setiap siswa terkait wirausaha produk kreatif

Dengan demikian, salah satu media yang dapat dimanfaatkan peserta didik untuk belajar mandiri adalah menggunakan media video produk kreatif wadah laptop. Penggunaan video sebagai media belajar dapat membuat peran guru ke arah yang lebih positif dan produktif. Guru dapat berbagi peran dengan media sehingga memiliki banyak waktu untuk memberi perhatian pada aspekaspek edukatif lainnya, seperti membantu kesulitan belajar siswa, pembentukan kepribadian, memotivasi belajar, dan lain-lain. Dengan penggunaan video ini, maka guru tidak harus menjelaskan materi ajaran secara berulang-ulang. Khususnya untuk media berupa video, jika dibutuhkan, materi dapat disajikan kembali cukup dengan menayangkan ulang (review). Apabila selama ini sebagian potensi guru tercurahkan kepada penyajian materi belajar di depan kelas,apabila penyajian materi secaara konvensional di depan kelas dapat dikurangi, maka perhatian guru dapat lebih diarahkan kepada pengembangan dan pendalaman. Dan dengan adanya pengembangan media belajar yang cocok digunakan untuk membantu siswa belajar secara mandiri akan berdampak positif bagi kualitas pendidikan itu sendiri. 


\section{TINJAUAN PUSTAKA}

\section{Pendidikan Kewirausahaan (Entrepreneur)}

Kewirausahaan seringkali disandingkan dengan kata entrepreneur dalam bahasa Inggris. Sejak abad ke-17 kata ini sudah mulai dikenal terutama di tempat asal kata ini muncul, yakni Perancis. Dalam bahasa ibunya, entreprendre atau yang kemudian biasa dikenal dengan entrepreneur mengandung arti berusaha, menjalankan atau melakukan, disandingkan dengan to set about dan to attempt yang berarti memulai dan mencoba. Dalam bahasa Indonesia, kata ini memang sejajar dengan wirausaha, yakni gabungan dari kata wira yang artinya berani, gagah atau perkasa dan usaha yang berarti bisnis. Dari term-term tersebut, entrepreneur atau wirausaha bisa dipahami sebagai suatu bentuk usaha yang dijalankan oleh seseorang yang punya keberanian (Nasution, 2007).

Kewirausahaan sebagai sebuah ilmu, sebuah ciri yang terdiri dari sifat atau watak, dan bisa mengandung seni dalam berperilaku. Di katakan bahwa orang yang memiliki jiwa kewirausahaan juga mempunyai kemampuan mewujudkan gagasan yang kreatif dan inovatif dalam realita kehidupan (Suharyono, 2017). Menurut Wiratno, (2012) kewirausahaan ialah yang mencerminkan sikap dan perilaku individu yang punya semangat pantang menyerah, bisa jadi teladan karena sudah berani mengambil kesempatan dan menghadapi resiko, yang sudah dipertimbangkan sebelumnya. Seorang wirausaha atau wiraswasta juga memiliki kemampuan dan kemauan yang kuat untuk berwirausaha.

Menurut Wibowo, (2017) kewirausahaan dapat dipahami sebagai semua jenis pekerjaan yang bisa ditekuni oleh seseorang, bisa berdagang, swasta, pengusaha sampai karyawan pemerintahan. Semua itu bisa masuk kategori wirausaha asalkan di dalamnya terdapat upaya yang inovatif dan daya kreatif untuk menciptakan peluang, ide-ide segar sehingga bisa dipakai untuk mengembangkan sumber daya yang sudah ada. Hal ini karena kewirausahaan selalu identik dengan peluang dan perbaikan. Jadi apapun usaha yang di dalamnya terkandung upaya-upaya pengembangan peluang yang kreatif dan inofatif, maka pasti bisa dikategorikan kewirausahaan.

Setiap kegiatan disadari atau tidak tentu mempunyai tujuan, apalagi kegiatan pembelajaran entrepeneurship. Tujuan sebagai sesuatu yang dikehendaki. Hal yang ingin dicapai dalam pembelajaran entrepeneurship ialah tertanam atau terbentuknya jiwa wirausaha pada diri seseorang, sehingga yang bersangkutan menjadi seorang wirausaha dengan kompetensinya. Sementara itu menurut Bygrave yang dikutip oleh Suherman salah satu faktor pendorong inovasi ialah kreativitas. Dengan demikian tujuan utama pembelajaran entrepeneurship pada prinsipnya ialah mencetak wirausaha yang kreatif, dalam artian individu yang memiliki kreativitas yang tinggi dalam melaksanakan kegiatan hidupnya kelak, khususnya di dunia usaha atau profesi lainnya (Suherman, 2010).

Pendidikan entrepeneurship bertujuan untuk antara lain:

a. Mengerti apa peranan perusahaan dalam sistem perekonomian

b. Keuntungan dan kelemahan berbagai bentuk perusahaan

c. Mengetahui karakteristik dan proses kewirausahaan

d. Mengerti perencanaan produk dan proses pengembangan produk

e. Mampu mengidentifikasikan peluang bisnis dan menciptakan kreativitas serta membentuk organisasi kerjasama

f. Mampu mengidentifikasi dan mencari sumber - sumber

g. Mengerti dasar- dasar : marketing, financial, organisasi, produksi,.

h. Mampu memimpin bisnis, mengahdapi tantangan masa depan (Alma, 2008)

Kewirausahawan adalah orang yang mengombinasikan faktor-faktor produksi, seperti sumber daya alam, tenaga kerja, material dan peralatan lainnya untuk meningkatkan nilai yang lebih tinggi dari sebelumnya. Wirausahawan merupakan orang yang memperkenalkan perubahan-perubahan, 
inovasi dan perbaikan produksi lainnya. Terdapat delapan karakteristik wirausahawan yang meliputi:

a. Rata tanggung jawab, yaitu memiliki rasa tanggung jawab atas usaha-usaha yang dilakukannya. Seseorang yang memiliki rasa tanggung jawab akan selalu berkomitmen dan wawas diri.

b. Memilih risiko yang moderat, yaitu lebih memilih risiko yang moderat, artinya selalu menghindari risiko, baik yang terlalu rendah maupun terlalu tinggi.

c. Percaya diri terhadap kemampuan sendiri, yaitu memiliki kepercayaan diri atas kemampuan yang dimilikinya untuk memperoleh kesuksesan.

d. menghendaki umpan balik segera yaitu selalu menghendaki adanya umpan balik dengan segera, ingin cepat berhasil.

e. semangat dan kerja keras yaitu memiliki semangat dan kerja keras untuk mewujudkan keinginannya demi masa depan yang lebih baik.

f. Berorientasi ke depan yaitu berorientasi masa depan dan memiliki perspektif dan wawasan jauh ke depan.

g. Memiliki keterampilan berorganisasi yaitu memiliki keterampilan dalam mengorganisasikan sumber daya untuk menciptakan nilai tambah.

h. Menghargai prestasi, yaitu lebih menghargai prestasi daripada uang (Suryana, 2013).

Seorang wirausahawan selalu berkomitmen dalam melakukan tugasnya hingga memperoleh hasil yang diharapkan. Ia tidak setengah-setengah dalam melakukan pekerjaan karena itu ia selalu tekun, ulet, dan pantang menyerah. Tindakannya tidak didasari oleh spekulasi, melainkan perhitungan yang matang. Ia berani menghadapi risiko terhadap pekerjaannya yang didukung oleh komitmen yang kuat mendorong seorang wirausahawan untuk terus berjuang mencari peluang hingga memperoleh hasil.

\section{Media Audio Visual}

Media adalah suatu ekstensi manusia yang memungkinkannya mempengaruhi orang lain yang tidak mengadakan kontak langsung dengan dia (Azhari, 2015). Media Audio Visual berasal dari kata media yang berarti bentuk perantara yang digunakan oleh manusia untuk menyampaikan atau menyebar ide, gagasan, atau pendapat sehingga ide, pendapat atau gagasan yang dikemukakan itu sampai kepada penerima yang dituju (Nurul Azmi, 2010). Media Audio Visual yaitu jenis media yang selain mengandung unsur suara juga mengandung unsur gambar yang dapat dilihat, seperti rekaman video, berbagai ukuran film, slide suara, dan lain sebagainya. Kemampuan media ini dianggap lebih baik dan lebih menarik, sebab mengandung kedua unsur jenis media yang pertama dan kedua (Mulyadi, Febry Fahreza, 2018). Dengan demikian dapat disimpulan bahwa media audio visual adalah media pengajaran dan media pendidikan yang mengaktifkan mata dan telinga peserta didik dalam waktu proses belajar mengajar berlangsung.

Dalam proses pembelajaran kehadiran media mempunyai arti yang cukup penting. Karena dalam kegiatan tersebut ketidakjelasan bahan yang akan disampaikan dapat dibantu dengan menghadirkan media sebagai perantara (Badriyah, 2015). Salah satu teknologi dalam proses pengajaran itu adalah memilih media pembelajaran. Media pembelajaran adalah seluruh alat dan bahan yang dapat dipakai untuk tujuan pendidikan, seperti radio, televisi, buku, koran, majalah, dan sebagainya (Sanjaya, 2011: 204). Media pembelajaran inilah yang akan membantu memudahkan siswa dalam mencerna informasi pengetahuan yang disampaikan. Media pembelajaran menurut karakteristik pembangkit rangsangan indera dapat berbentuk Audio (suara), Visual (gambar), maupun Audio Visual. Pengajaran melalui audio visual jelas bercirikan pemakaian perangkat keras selama proses belajar, seperti mesin proyektor film, televisi, tape recorder dan proyektor visual yang lebar (Mawarni, Sukirwan, \& V. Y, 2020). 


\section{METODE}

Penelitian ini termasuk dalam jenis penelitian teoritis yaitu studi kepustakaan (Library Research) yaitu studi kepustakaan. Hal ini dimaksudkan untuk menghimpun data dan informasi lain yang mempunyai kaitan dengan topik penelitian ini. Kajian pustaka yaitu penampilan argumentasi penalaran keilmuan yang memaparkan hasil penelitian pustaka dan hasil pemikiran peneliti mengenai suatu masalah (topik), hasil kajian pustaka semacam ini berisi satu topik yang didalamnya memuat beberapa gagasan dan informasi dari sumber pustaka (literature), bahan-bahan pustaka yang dipakai harus dibahas secara kritis dan mendalam dalam rangka mendukung gagasan atau proposisi untuk menghasilkam kesimpulan dan saran. Dari istilah diatas dapat dikatakan pula bahwa penelitian ini merupakan penelitian yang lebih berorientasi pada penggalian data, atau tepatnya referensi yang berasal dari karya ilmiah, atau karya tulis yang sudah ada sebelumnya.

Sumber data adalah subyek dari mana data dapat diperoleh (Arikunto, 2010), sumber data ini meliputi data primer dan data sekunder: 1) Sumber Data Primer yaitu bahan pustaka yang berisikan pengetahuan ilmiah yang baru atau mutakhir, ataupun pengertian baru tentang fakta yang diketahui maupun mengenai gagasan (ide) yaitu buku, jurnal ilmiah, buletin dan sebagainya. 2) Sumber Data Sekunder yaitu bahan pustaka/sumber data sebagai penunjang seperti semua buku yang ada hubungannya dengan judul skripsi ini secara tidak langsung.

Metode dan instrumen pengumpulan data yang digunakan dalam kajian ini adalah metode dokumentasi yaitu cara pencarian data dari hal-hal yang akan dibahas ataupun teori-teori yang akan digunakan dalam rumusan data yang kemudian disimpulkan (Arikunto, 2010). Data ini dapat berupa buku, jurnal ilmiah, buletin dan sebagainya.

Teknik analisa data yang digunakan yaitu content analysis yaitu metode yang lebih mengedepankan pada pengungkapan aspek isi (esensi) dari beberapa proposisi yang ada. Lebih lanjut metode ini merupakan watak dari peninjauan berbagai teori dan analisis. Kajian isi sebagai teknik penelitian untuk keperluan mendeskripsikan secara obyektif, sistematis dan kuantitatif tentang manifestasi komunikasi. Weber yang dikutip oleh (Abdurrahman, 2009) menyatakan bahwa content analysis adalah metodologi penelitian dari sebuah dokumen. Kajian isi adalah teknik penelitian yang dimanfaatkan untuk menarik kesimpulan yang replikatif dan sahih dari data atas dasar konteksnya.

\section{PEMBAHASAN}

\section{Pembelajaran Produk Kreatif di Sekolah}

Produk kreatif sebagai sebuah produk yang telah mendapat perlakuan/modifikasi sehingga menjadi sesuatu yang baru. Anjaningrum \& Sidi (2018) berpendapat bahwa produk kreatif menekankan pada apa yang dihasilkan dari proses kreativitas adalah sesuatu yang baru, orisinil, dan bermakna. Kreativitas adalah kemampuan seseorang untuk melahirkan sesuatu yang baru, baik berupa gagasan maupun karya nyata, baik dalam karya baru maupun kombinasi dari hal-hal yang sudah ada, yang semuanya itu lokal berbeda dengan apa yang telah ada sebelumnya.

Kreativitas dan inovasi merupakan inti dari kewirausahaan. Kreativitas dapat dipandang sebagai kemampuan untuk mengembangkan ide-ide baru dan untuk menemukan cara-cara baru dalam melihat masalah dan peluang. Sedangkan inovasi dalam kewirausahaan adalah kemampuan untuk menerapkan solusi kreatif terhadap masalah dan peluang untuk meningkatkan atau untuk memperbaiki kinerja usaha. Dengan demikian, dapat disimpulkan bahwa produk kreatif dan kewirausahaan ialah upaya penciptaan produk baru yang dihasilkan dari proses kreatif serta memperhatikan nilai - nilai kewirausahaan dimana produk tersebut memiliki kelebihan dari produk lain yang telah ada dan memiliki nilai jual.

Melalui pembelajaran produk kreatif dan kewirausahaan siswa diharapkan dapat memahami sikap dan perilaku wirausahawan, menganalisis konsep desain/prototy produk barang dan jasa, 
menerapkan strategi teknik pemasaran serta membuat perencanaan bisnis (Khotimah, Kantun, \& Widodo, 2020). Secara lebih rinci Anjaningrum \& Sidi (2018) menyebutkan tujuan mengapa siswa perlu belajar produk kreatif, diantaranya :

a. Mengasah keterampilan para siswa dengan membuat dan menciptakan produk yang sesuai dengan minat dan daya beli.

b. Meningkatkan daya inovasi dan kreatifitas siswa melalui pembuatan berbagai produk.

c. Membudayakan semangat, sikap, perilaku dan kemampuan berwirausaha siswa.

d. Mewujudkan kemantapan siswa untuk menghasilkan kemajuan melalui pembuatan produk kreatif.

e. Menciptakan iklim belajar, bekerja, berkarya dan berpartisipasi dalam pembelajaran yang menyenangkan.

\section{Manfaat dari Pembelajaran Produk Kreatif di Sekolah}

Manfaat dari pembelajaran produk kreatif di sekolah, tentu sangatlah banyak salah satunya adalah tumbuhnya kemampuan berpikir dan kemampuan bekerja keras dari para siswa. Dan berikut ini adalah manfaat dari pembelajaran produk kreatif menurut:

a. Menerapkan perilaku tepat waktu .

b. Menerapkan perilaku tepat janji.

c. Membentuk pribadi yang disiplin.

d. Membentuk pribadi yang ulet dan mau bekerja keras.

e. Membentuk pribadi yang memiliki jiwa toleran dan mau menolong sesama.

f. Menjadi contoh bagi masyarakat sebagai pribadi yang unggul dan patut diteladani (Rianto, Suyadi, \& Kartini, 2018)

\section{Alat dan Bahan serta langkah-langkah dalam pembuatan Softcase Laptop Produk Kreatif}

Alat dan bahan :

a. dua kain untuk bagian depan ( $39 \mathrm{~cm} \times 28 \mathrm{~cm}$ ) dan lapisan untuk bagian dalam ( $39 \mathrm{~cm} \times 28 \mathrm{~cm}$ )

b. dua kapas perekat antar muka yang keras tanpa jahitan

c. Potongn kain untuk bagian $(39 \mathrm{~cm} \times 4 \mathrm{~cm}$ ) ritsleting atas

d. ritsleting $(39 \mathrm{~cm}$ )

e. ( saku lapisan luar ) satu kain utama dan kain lapisan $(39 \mathrm{~cm} \times 22 \mathrm{~cm}$ )

f. (saku bagian dalam) dua kain utama dan kain lapisan $(39 \mathrm{~cm} \times 26 \mathrm{~cm})$,

satu kain utama dan kain lapisan $(28 \mathrm{~cm} \times 20 \mathrm{~cm})(28 \mathrm{~cm} \times 15 \mathrm{~cm})$

g. Pita kain $(120 \mathrm{~cm})$, ritsleting $(93 \mathrm{~cm})$, ujung ritsleting dari kain utama dan kain pelapis $(24 \mathrm{~cm} \times 3$ $\mathrm{cm})$.

Langkah-langkah pembuatan :

a. kapas perekat dipotong ditiap sisinya dengan ukuran $2 \mathrm{~cm}$ menjadi lengkung

b. Pasang kain perekat pada kain utama setrika dan potong bagian tiap sisi kain utama $1 \mathrm{~cm}$ begitupun dengan kain pelapisnya

Proses selanjutnya membuat saku lapisan luar:

a. Kain utama bagian luar dihdapkan dengan kain pelapis bagian luar lalu jahit

b. kain di bagian atas ritsleting dilipat dua kali dan jahit bagian atas

c. pasang saku luar

Proses membuat kantong laptop dan kantong bagian dalam serta disatukan semuanya:

a. Kain bagian dalam dijahit saling berhadapan dengan pita kain

b. Saku laptop direkomendasikan untuk ditempelkan kapas perekat juga

c. Pasang saku bagian dalam ke lapisan

d. Jahit ujung ritsleting

e. Bagian depan kain saling berhadapan dan dijahit, jahit pada bagian atas

f. Pasang ritsleting 
g. Menjahit kain bagian luar, menjahitnya di mana Anda akan membalikkan lapisan

h. Jahit posisi pertama permukaan luar reversibel

i. Kain bagian depan saling berhadapan

j. Jahit posisi ujung permukaan luar reversibel

k. Jahit di bagian atas ritsleting

1. Jahit bagian masuk kantong

$\mathrm{m}$. Dan penyelesaian yang terakhir jahit area samping kantong bagian dalam

\section{KESIMPULAN}

Kewirausahaan dapat mencerminkan sikap dan perilaku individu yang punya semangat pantang menyerah, bisa jadi teladan karena sudah berani mengambil kesempatan dan menghadapi resiko, yang sudah dipertimbangkan sebelumnya. Seorang wirausaha atau wiraswasta juga memiliki kemampuan dan kemauan yang kuat untuk berwirausaha. Produk kreatif menekankan pada apa yang dihasilkan dari proses kreativitas adalah sesuatu yang baru, orisinil, dan bermakna. Produk kreatif dan kewirausahaan ialah upaya penciptaan produk baru yang dihasilkan dari proses kreatif serta memperhatikan nilai - nilai kewirausahaan dimana produk tersebut memiliki kelebihan dari produk lain yang telah ada dan memiliki nilai jual. Melalui pembelajaran produk kreatif dan kewirausahaan siswa diharapkan dapat memahami sikap dan perilaku wirausahawan, menganalisis konsep desain/prototy produk barang dan jasa, menerapkan strategi teknik pemasaran serta membuat perencanaan bisnis. Media audio visual sebagai media pengajaran dan media pendidikan yang mengaktifkan mata dan telinga peserta didik dalam waktu proses belajar mengajar berlangsung. Dalam proses pembelajaran kehadiran media mempunyai arti yang cukup penting. Karena dalam kegiatan tersebut ketidakjelasan bahan yang akan disampaikan dapat dibantu dengan menghadirkan media sebagai perantara. Manfaat dari pembelajaran produk kreatif di sekolah, tentu sangatlah banyak salah satunya adalah tumbuhnya kemampuan berpikir dan kemampuan bekerja keras dari para siswa. Proses pembelajaran menjadi lebih bermakna dan siswa pun merasa lebih bergembira dalam menerima pelajaran. Cara pembuatan yang sederhana pun akan membuat para guru tidak terlalu sulit dalam membimbing siswa dalam proses pemilihan, pembuatan, dan pemeliharaannya.

\section{DAFTAR PUSTAKa}

Abdurrahman, S. dan. (2009). Metode Penelitian. Jakarta: Rineka Cipta.

Alma, B. (2008). Kewirausahaan Untuk Mahasiswa dan Umum. Bandung: Alfabeta.

Anjaningrum, W. D., \& Sidi, A. P. (2018). Kreatifitas dan inovasi produk industri kreatif. Conference on Innovation and Application of Science and Technology, (September), 61-70.

Argaheni, N. B. (2020). Sistematik Review: Dampak Perkuliahan Daring Saat Pandemi COVID-19

Terhadap Mahasiswa Indonesia. PLACENTUM: Jurnal Ilmiah Kesehatan dan Aplikasinya, 8(2), 99. https://doi.org/10.20961/placentum.v8i2.43008

Arikunto, S. (2010). Prosedur Penelitian Suatu Pendekatan Praktik. Jakarta: Rineka Cipta.

Azhari, A. (2015). Peran Media Pendidikan Dalam Meningkatkan Kemampuan Bahasa Arab Siswa Madrasah. Jurnal Ilmiah Didaktika, 16(1), 43. https://doi.org/10.22373/jid.v16i1.586

Badriyah. (2015). Efektifitas Proses Pembelajaran Dengan Pemanfaatan Media Pembelajaran. Jurnal Lentera Komunikasi, 1(1), 21-36.

Ekawati, N., Wahyuningsih, D., \& Fisika, P. (2012). Pengembangan Video Tutorial Sebagai Media Dalam Belajar Mandiri Materi Bunyi, 148-158.

Khotimah, P. C., Kantun, S., \& Widodo, J. (2020). Kewirausahaan Terhadap Minat Berwirausaha Siswa Di Smk Negeri 7 Jember ( Studi Kasus Pada Kelas Xii Program Keahlian Multimedia Semester Gasal Tahun Ajaran 2019 / 2020 ). Jurnal Pendidikan Ekonomi, 14, 357-360. 
https://doi.org/10.19184/jpe.v14i2.16522

Mawarni, G. A., Sukirwan, S., \& V. Y, I. A. (2020). Pengembangan Media Pembelajaran Ludo Smart

Geometryberbasis Ekspedisi Budaya Bantenpada Siswa Kelas V a Di Sdn Cogreg 1 Tangerang

Banten. Indonesian Journal of Elementary Education (IJOEE), 1(2), 28-41.

https://doi.org/10.31000/ijoee.v1i2.2929

Mulyadi, Febry Fahreza, dan R. J. (2018). Jurnal Visipena Volume 9, Nomor 1, Juni 2018I

31penggunaanmedia Audio Visual Untuk Meningkatkan Prestasi Belajar Pada Pembelajaran Ips

Siswa Kelas V Sdn Langung. Jurnal Visipena, 151(2), 10-17.

Nasution, A. H. (2007). Entrepreneurship, Membangun Spirit Teknopreneurship. Yogyakarta: Andi Offset.

Nurul Azmi, B. S. dan E. M. (2010). Penerapan Media Audio Visual Dalam Pembelajaran Bahasa Arab Untuk Meningkatkan Penguasaan Mufrodat (Kosa Kata) Pada Siswa Kelas Xi Sma

Muhammadiyah Limbung, 8719(2006), 1-10.

Rianto, D., Suyadi, B., \& Kartini, T. (2018). Perilaku Kreatif Dan Inovatif Petani Dalam Usaha Budidaya Buah Belimbing Di Kelurahan Karangsari Kecamatan Sukorejo Kota Blitar. JURNAL PENDIDIKAN EKONOMI: Jurnal Ilmiah Ilmu Pendidikan, Ilmu Ekonomi dan Ilmu Sosial, 12(1), 105. https://doi.org/10.19184/jpe.v12i1.7594

Rintan Saragih. (2017). Membangun Usaha Kreatif, Inovatif Dan Bermanfaat Melalui Penerapan Kewirausahaan Sosial. Jurnal Kewiraushaan, 3(2), 50-58.

Sa'diyah, R. (2017). pentingnya melatih kemandirian anak. KORDINAT, XVI(1), 31-46.

Suharyono. (2017). Sikap dan Perilku Wirausahawan. Ilmu dan Budaya, 40(56), 6551-6586.

Suherman, E. (2010). Desain Pembelajaran Kewirausahaan. Bandung: Alfabeta.

Suryana. (2013). Kewirausahaan. jakarta: Salemba Empat.

Wibowo, D. P. dan A. (2017). Pendidikan Kewirausahaan. Yogyakarta: Pustaka Pelajar.

Wiratno, S. (2012). The implemtation of enterpreneurship education in the higher education. Jurnal Pendidikan dan Kebudayaan, 18(4), 453-466. 